\title{
Essay/Personal Reflections
}

KEN BRYSON $91 \quad$ Guidelines for conducting a spiritual assessment

\section{Poetry/Fiction}

NANCY HENESON $99 \quad$ Immortal

\section{Letter to the Editor}

PÄR SALANDER 101 Whether "spirituality" can be a meaningful concept is still open to question

\section{Corrigendum}

D. LAMBIE, R. EGAN, 103

How spirituality is understood and taught in New Zealand

S. WALKER,

medical schools-Corrigendum 


\section{PALLIATIVE \& SUPPORTIVE CARE \\ Volume 13 \\ February, 2015 \\ Number 1}

WILLIAM BREITBART

BEHICE ERCI

MONIKA KÖGLER, MONIKA BRANDSTÄTTER, GIAN DOMENICO BORASIO, VERONIKA FENSTERER, HELMUT KÜCHENHOFF, AND MARTIN JOHANNES FEGG

EMMA M. STEIN, EVELYN KOLIDAS, AND ALYSON MOADEL

NICOLAS VONARX

LINDA GANZINI, ALEXA RAKOSKI, SHARILYN COHN, AND RICHARD A. MULARSKI

STEPHANIE CLEMM, RALF J. JOX, GIAN DOMENICO BORASIO, AND TRAUGOTT ROSER

D. LAMBIE, R. EGAN, S. WALKER, AND R. MACLEOD

MICHIYO ANDO, YUKIHIRO SAKAGUCHI, YASUFUMI SHIIHARA, AND KUMI IZUHARA

MATRA ROBERTSON

THE REVEREND MiCHELE SHIELDS, ALLISON KESTENBAUM, AND LAURA B. DUNN

3

\section{CONTENTS}

\section{From the Editor}

Special Issue on Spirituality in Palliative and Supportive Care: Who are we Talking to When we are Talking to Ourselves?

\section{Original Articles}

Meaning in life of patients with cancer

Mindfulness in informal caregivers of palliative patients

Do spiritual patients want spiritual interventions?: A qualitative exploration of underserved cancer patients' perspectives on religion and spirituality

27 Cancer patients and spiritual experiences: Redefining the self through initiatory ordeals

41 Family members' views on the benefits of harp music vigils for terminally-ill or dying loved ones

The role of chaplains in end-of-life decision making: Results of a pilot survey

How spirituality is understood and taught in New Zealand medical schools

Changes experienced by and the future values of bereaved family members determined using narratives from bereavement life review therapy

Experiences of time: A qualitative inquiry into experiences of time as described by palliative care inpatients

\section{Review Article}

Spiritual AIM and the work of the chaplain: A model for assessing spiritual needs and outcomes in relationship 